\title{
Pathogenicity of Pseudomonas syringae pv. tomato on Tomato Seedlings: Phenotypic and Gene Expression Analyses of the Virulence Function of Coronatine
}

\author{
Srinivasa Rao Uppalapati, ${ }^{1,2}$ Yasuhiro Ishiga, ${ }^{1}$ Tamding Wangdi, ${ }^{1}$ Ewa Urbanczyk-Wochniak, ${ }^{2}$ \\ Takako Ishiga, ${ }^{1}$ Kirankumar S. Mysore ${ }^{2}$ and Carol L. Bender ${ }^{1}$ \\ ${ }^{1}$ Department of Entomology and Plant Pathology, Oklahoma State University, Stillwater, OK 74078, U.S.A.; ${ }^{2}$ Plant Biology \\ Division, The Samuel Roberts Noble Foundation Inc., 2510 Sam Noble Parkway, Ardmore, OK 73401, U.S.A.
}

Submitted 9 October 2007. Accepted 11 December 2007.

\begin{abstract}
Bacterial speck disease, which is caused by Pseudomonas syringae pv. tomato, is an economically important disease on tomato. In the present study, we show that $P$. syringae pv. tomato $\mathrm{DC} 3000$ is a pathogen of tomato seedlings, an aspect of pathogen biology that has not been previously investigated. This resulted in the development of a virulence assay on tomato seedlings that has several advantages over labor-intensive foliar assays, including a shorter growth and incubation period, ease of inoculation and handling, and rapid generation of larger sample sizes per experiment. The utility of this assay was investigated by exploring the virulence function of coronatine (COR) on tomato seedlings. Using the $\mathrm{COR}^{-}$mutant DB29 and a MAPMAN display of transcript data from TOM1 microarrays, CORdependent expression of genes involved in secondary metabolism, polyamine biosynthesis, reactive oxygen species homeostasis, and the novel transcription factor SINAC2 were identified. Furthermore, during pathogenesis, genes involved in photosynthetic light reactions and the CalvinBenson cycle were strongly repressed by COR. In conclusion, we show that $P$. syringae pv. tomato infects tomato seedlings and that COR is required for virulence in seedlings. The seedling assay can be used in high-throughput screens for the identification of molecular targets for COR and for the identification of genes involved in pathogenesis.
\end{abstract}

Additional keywords: chlorosis, jasmonic acid, phytohormone, senescence, Solanum lycopersicum.

Bacterial speck disease, which is caused by Pseudomonas syringae pv. tomato, is an economically important disease of tomato. P. syringae pv. tomato causes necrotic lesions on the

\section{S. R. Uppalapati and Y. Ishiga contributed equally to this manuscript.}

Corresponding authors: S. R. Uppalapati; E-mail: srinivasaraou@yahoo.com; Telephone: +1.580 .224 .6180 ; Fax: +1.580 .224 .6692 or C. L. Bender; E-mail: carol.bender@okstate.edu; Telephone: +1.405.744.945; Fax: +1 . 405.744.7373.

* The $\boldsymbol{e}$-Xtra logo stands for "electronic extra" and indicates supplemental material is published online. Supplemental results as well as five additional figures and five additional tables appear online. leaves, stems, and fruit of tomato plants (Goode and Sasser 1980). Fruit lesions are slightly raised and vary in size from tiny flecks to visible lesions approximately $3 \mathrm{~mm}$ in diameter (Goode and Sasser 1980). Fruit infection can lead to infestation of tomato seed, and $P$. syringae pv. tomato can survive on seeds, especially inside cavities present on the seed surface (Devash et al. 1980). Seedlings from infested seeds either develop visible disease symptoms or remain symptomless; in the latter case, asymptomatic plants grown under high relative humidity contain massive populations of the pathogen, thus serving as a reservoir for future infections (McCarter et al. 1983). Although several reports have suggested that $P$. syringae pv. tomato is seed-borne (Bashan et al. 1982) and can spread through tomato transplant fields (Gitaitis 1990), these aspects of disease etiology and pathogen biology are not well understood.

Bacterial speck disease of tomato is largely regarded as a foliar disease (Preston 2000), and studies on the P. syringae pv. tomato-tomato interaction have primarily been conducted in the leaves of 3- to 4-week-old tomato plants. Foliar assays generally require high relative humidity to enable pathogen entry and development of typical disease symptoms following dip or spray inoculation (Lund et al. 1998; Peñaloza-Vázquez et al. 2000; Uppalapati et al. 2007; Zhao et al. 2003). Unfortunately, these assays require extensive growth-chamber or greenhouse space and are labor intensive. Thus, the development of reliable seedling assay for $P$. syringae pv. tomato-tomato interactions could reduce both the time and space needed for virulence assays.

The foliar lesions induced by $P$. syringae pv. tomato are generally surrounded by a yellow chlorotic halo due to production of the phytotoxin coronatine (COR) (Bender et al. 1987, 1999). The COR molecule has an unusual structure and consists of two components: coronafacic acid (CFA), a polyketide, and coronamic acid (CMA), an ethylcyclopropyl amino acid derived from alloisoleucine (Couch et al. 2004; Ichihara et al. 1977; Parry et al. 1994; Vaillancourt et al. 2005). Both the CFA and CMA components of COR were shown to contribute to the development of wild-type symptoms in tomato foliage (Uppalapati et al. 2007). COR plays several important roles during $P$. syringae pv. tomato pathogenesis. Recent studies in Arabidopsis demonstrate that COR facilitates the entry of $P$. syringae pv. tomato into foliar tissue by suppressing the clo- 
sure of stomata, a basal defense response induced upon microbial attack (Melotto et al. 2006). COR is also required for the growth and persistence of $P$. syringae pv. tomato in the foliage of tomato, Arabidopsis, and Brassica spp. (Bender et al. 1987; Brooks et al. 2004; Elizabeth and Bender 2007; Mittal and Davis 1995; Penaloza-Vazquez et al. 2000; Uppalapati et al. 2007).

P. syringae pv. tomato DC3000 is a model strain for investigating plant-microbe interactions due to its genetic tractability and pathogenicity on tomato, Arabidopsis, and Brassica spp. (Cuppels 1986; Elizabeth and Bender 2007; Whalen et al. 1991). Genetic studies using defined $\mathrm{CFA}^{-}$and $\mathrm{CMA}^{-}$mutants of $P$. syringae pv. tomato DC3000 indicated that the intact COR molecule must be produced for maximal virulence on Arabidopsis, tomato, and Brassica spp. (Brooks et al. 2004, 2005; Elizabeth and Bender 2007; Uppalapati et al. 2007). However, it is not known whether $P$. syringae pv. tomato DC3000 infects tomato seedlings and if COR functions to promote virulence in seedling tissue.

Using mutants defective in COR biosynthesis, it has been demonstrated that COR activates jasmonic acid (JA) biosynthesis and JA-mediated signaling and also functions to suppress salicylic acid (SA)-mediated defense responses in tomato (Uppalapati et al. 2005, 2007; Zhao et al. 2003). However, unlike Arabidopsis, COR has additional roles in virulence that are SA independent (Uppalapati et al. 2007). Furthermore, purified COR elicits visible chlorosis on tomato leaves (Palmer and Bender 1996; Uppalapati et al. 2005) but not on Arabidopsis (Bent et al. 1992). These results suggest that COR may function differently in tomato and Arabidopsis.

In the present study, we describe a simple, inexpensive seedling-based assay that expedites the analysis of $P$. syringae pv. tomato-tomato interactions. Our results indicate that P. syringae pv. tomato DC3000 is a pathogen of tomato seedlings, an aspect of $P$. syringae pv. tomato DC3000 biology that has not been previously investigated. We also demonstrate the use of a tomato seedling assay to study $P$. syringae pv. tomato virulence and to identify host signaling pathways targeted by COR. Our results show that COR functions as an important virulence factor in tomato seedling disease development. Using the well-defined COR-defective mutant DB29 and a tomato microarray (TOM1), we identified several genes that may function in bacterial speck of tomato in a COR-dependent manner.
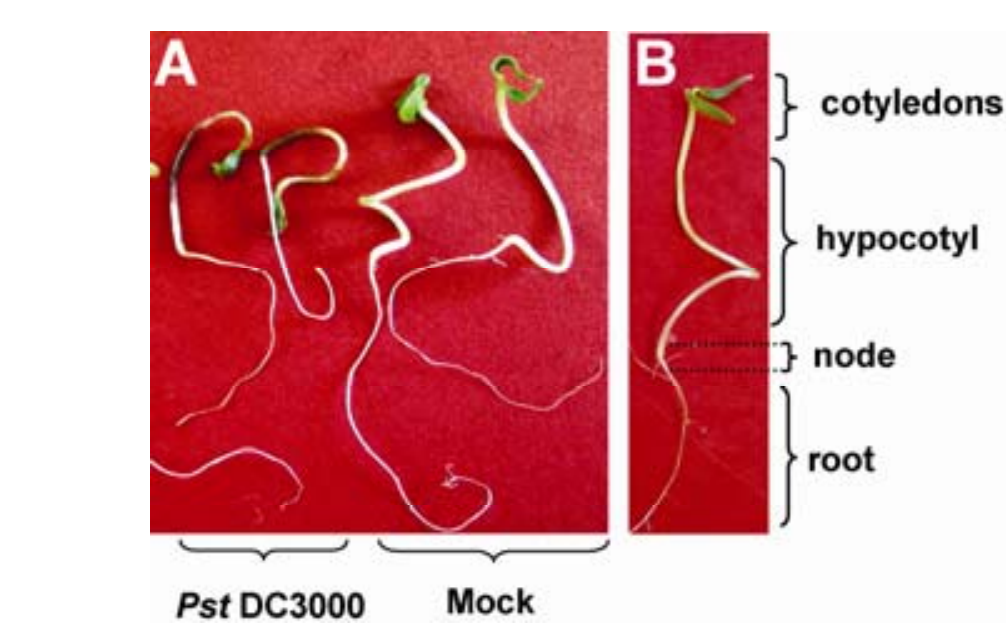

\section{RESULTS AND DISCUSSION}

\section{A seedling assay to study}

P. syringae pv. tomato DC3000-tomato interactions.

To obtain seedlings for the experiments, tomato (cv. Glamour) seeds were surface-sterilized and germinated in the dark. At 4 days postgermination, seedlings containing 2- to 3-cm-long hypocotyls were selected and the first pair of cotyledons was used for bacterial inoculation (Fig. 1A). Seedlings were inoculated by flooding MS (Murashige and Skoog) agar plates with a bacterial suspension until the seedlings were completely submerged in inoculum. The seedlings were exposed to the bacterial suspension for 2 to $3 \mathrm{~min}$ with gentle mixing, a process that did not dislodge or wound the seedlings. The bacterial suspension was then discarded, and inoculated tomato seedlings were incubated in a growth room with a 12-h photoperiod.

To study the effect of inoculum concentration on symptom development, tomato seedlings were immersed in three different concentrations of $P$. syringae pv. tomato $\mathrm{DC} 3000\left(\mathrm{OD}_{600}=0.01\right.$, 0.1 , or 1.0). Seedlings exposed to the highest concentration of bacteria $\left(\mathrm{OD}_{600}=1.0 ; 2 \times 10^{8}\right.$ to $\left.5 \times 10^{8} \mathrm{CFU} / \mathrm{ml}\right)$ exhibited severe necrotic symptoms within $24 \mathrm{~h}$ (data not shown) and were dead by 3 days postinoculation (dpi). Thus, an $\mathrm{OD}_{600}=1.0$ was deemed lethal for studying disease progression. However, seedlings inoculated with bacteria at an $\mathrm{OD}_{600}=0.1\left(2 \times 10^{7}\right.$ to $5 \times 10^{7} \mathrm{CFU} / \mathrm{ml}$ ) exhibited discrete necrotic lesions on the hypocotyl and cotyledons at 3 and 5 dpi, respectively (Fig. 1A). Closer inspection of $P$. syringae pv. tomato DC3000-inoculated seedlings indicated that the cotyledons showed extensive chlorosis (Fig. 2A), which is a hallmark of bacterial speck disease in foliar tissue; consequently, bacteria concentrated to an $\mathrm{OD}_{600}=0.1$ was used in all subsequent experiments.

In addition to symptom development, the virulence of $P$. syringae pv. tomato DC3000 is generally assessed by measuring bacterial growth in planta (Glazebrook et al. 1997; Tornero and Dangl 2001). In inoculated tomato seedlings, $P$. syringae pv. tomato DC3000 multiplied approximately 1,000-fold within the first $4 \mathrm{dpi}$, with the bacterial population remaining relatively constant for the rest of the assay period (Fig. 2G). These results are similar to the bacterial growth curves observed in tomato and Arabidopsis leaves of mature plants (Katagiri et al. 2002; Uppalapati et al. 2007; Zhao et al. 2003).

As described above, the inoculation procedure involved immersing the entire seedling in a bacterial suspension and then

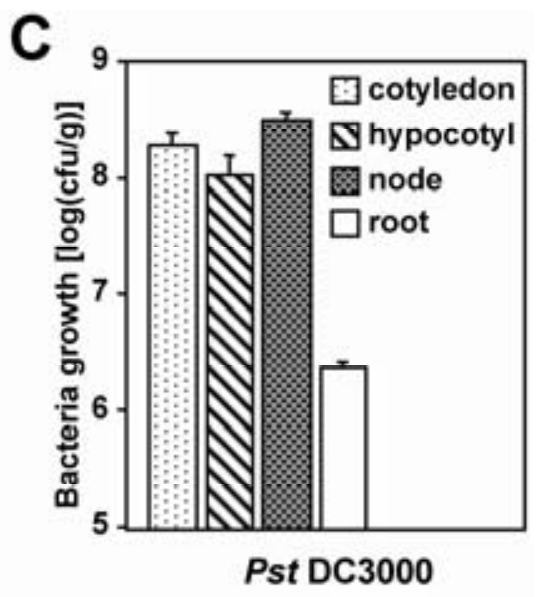

Fig. 1. A seedling assay for the analysis of Pseudomonas syringae pv. tomato DC3000 (Pst DC3000) interactions with tomato. A, Disease phenotype of seedlings immersed in a bacterial suspension of $P$. syringae pv. tomato DC3000. Photograph was taken 7 days postinoculation (dpi). Mock-inoculated seedlings were immersed in sterile distilled $\mathrm{H}_{2} 0$ containing $0.025 \%$ Silwet. B, Anatomical regions of tomato seedlings. C, Spatial distribution of $P$. syringae pv. tomato DC3000 in tomato seedlings inoculated by immersion in a bacterial suspension (optical density at $600 \mathrm{~nm}=0.1$ ). The population of $P$. syringae pv. tomato DC3000 in tomato seedling cotyledons, hypocotyls, nodes, and roots was sampled by dissecting seedling leaves, pooling samples, and measuring the population at $3 \mathrm{dpi}$. Vertical bars indicate the standard error for three independent experiments. 
evaluating virulence. To better understand the spatial distribution of $P$. syringae pv. tomato DC3000 in inoculated tomato seedlings, the internal population of $P$. syringae pv. tomato DC3000 was measured in cotyledons, hypocotyls, nodes, and roots (Fig. 1B and C). P. syringae pv. tomato DC3000 colonized the cotyledons, hypocotyls, and the nodal regions of the seedlings at high inoculum densities $\left(>10^{8} \mathrm{CFU}\right.$ per gram of tissue) (Fig. 1C). However, the population of bacteria recovered from roots was significantly lower (approximately $10^{6}$ CFU per gram of tissue), which is consistent with the absence of obvious disease symptoms in tomato seedling roots (Fig. 1A). Thus, $P$. syringae pv. tomato DC3000 preferentially colonizes the aerial portions of tomato seedlings, which is consistent with its identity as a foliar pathogen. However, it is important
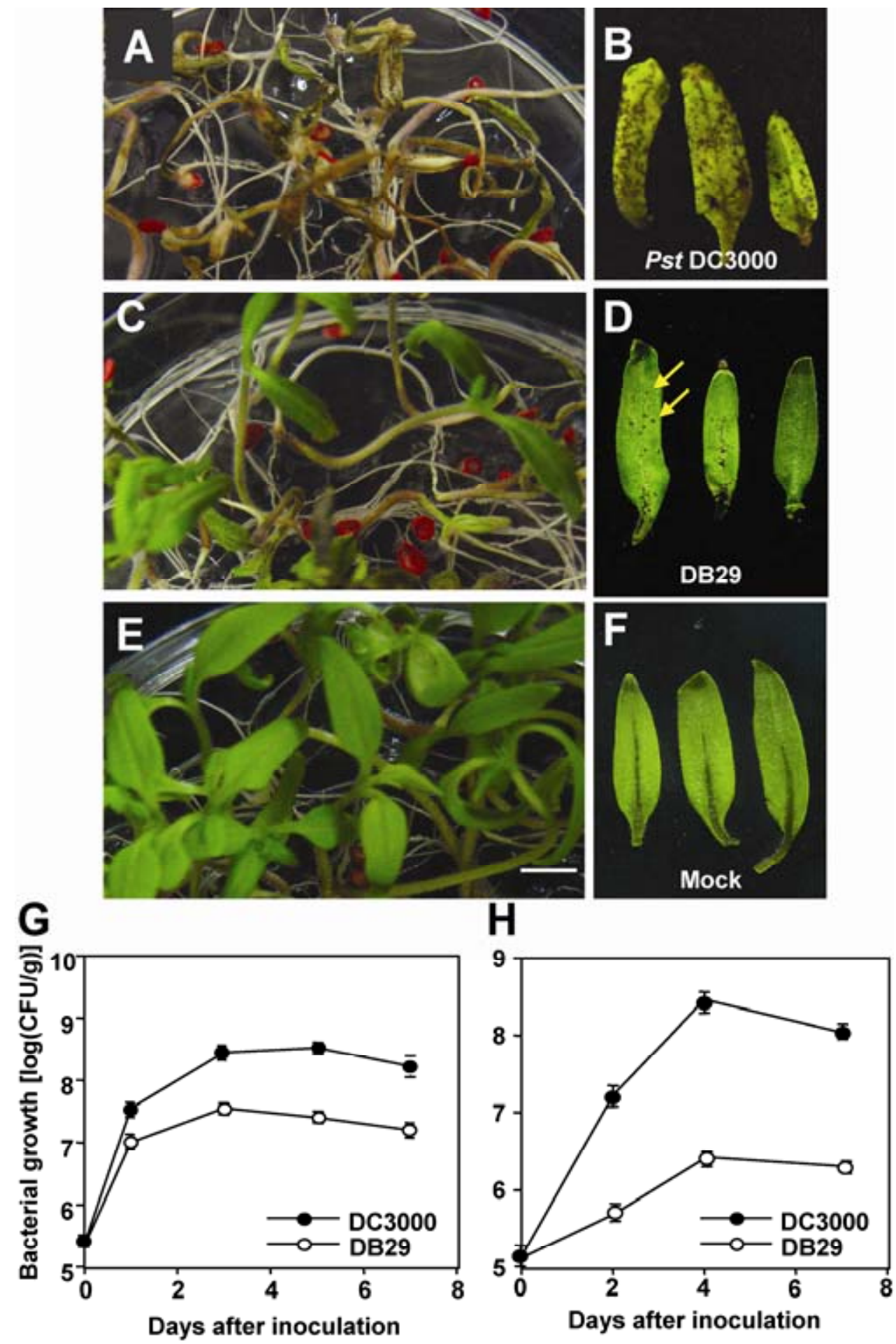

Fig. 2. Coronatine (COR) functions as a virulence factor in the pathogenesis of Pseudomonas syringae pv. tomato DC3000 (Pst DC3000) on tomato seedlings. A and $\mathbf{B}$, Disease phenotype of seedlings immersed in a suspension of $P$. syringae pv. tomato DC3000, $\mathbf{C}$ and $\mathbf{D}$, the COR ${ }^{-}$mutant DB29, or $\mathbf{E}$ and $\mathbf{F}$, sterile distilled water. A, C, and E, Intact inoculated seedlings on Murashige and Skoog agar plates. B, D, and F, Disease phenotype on individual cotyledons. Arrows in panel D show the location of small pinpoint necrotic lesions in DB29-inoculated seedlings; E, scale bar $=1 \mathrm{~cm}$. Photographs were taken 7 days postinoculation. G, Population of $P$. syringae pv. tomato DC3000 and DB29 in tomato seedlings and $\mathbf{H}$, seedling leaves (cotyledons). Bacterial populations were obtained by surface-sterilizing inoculated seedlings or cotyledons and, then, plating dilutions to selective media $0,1,3,5$, and 7 (G) or $0,2,4$, and 7 (H) dpi. Vertical bars indicate the standard errors for five independent experiments. 
to note that $P$. syringae pv. tomato DC3000 infected roots of Arabidopsis seedlings in liquid cultures (Bais et al. 2005).

To study the utility of tomato seedling assays to effectively identify the genes involved in pathogenesis, we used several well-characterized virulence mutants. Our results using vacuum infiltration of tomato seedlings with different $P$. syringae pv. tomato DC3000 mutants agreed well with previous results obtained by foliar inoculation of tomato plants (Supplementary Table S4; Supplementary Results; Wangdi 2007). In the current study, the seedling assay was investigated in detail by exploring the virulence function of COR on tomato seedlings.

\section{COR functions as a virulence factor in tomato seedlings.}

Previous studies using leaves of 3- to 4-week-old tomato plants indicated that the phytotoxin COR plays an important role in the pathogenicity of $P$. syringae pv. tomato DC3000 (Bender et al. 1987; Mittal and Davis 1995; Peñaloza-Vázquez et al. 2000; Uppalapati et al. 2007; Zhao et al. 2003). To further evaluate the utility of the tomato seedling assay and to assess whether COR functions in the virulence of $P$. syringae pv. tomato DC3000 on tomato seedlings, tomato seedlings were inoculated with $P$. syringae pv. tomato DC3000 and the $\mathrm{COR}^{-}$mutant DB29 (Brooks et al. 2004). P. syringae pv. tomato DC3000 caused severe necrosis on hypocotyls and cotyledons (Figs. 1A and 2A), and diffuse chlorosis developed at later stages (Fig. 2B). However, DB29-inoculated seedlings appeared relatively healthy (Fig. 2C); when examined closely, tiny necrotic lesions were observed on some of the cotyledons (Fig. 2D, arrows). Chlorosis was not observed on DB29-inoculated seedlings, which is consistent with the absence of COR production. The population of $P$. syringae pv. tomato DC3000 and DB29 in inoculated tomato seedlings was compared over a 7day period (Fig. 2G). The population of DB29 was significantly lower than $P$. syringae pv. tomato DC3000 at 2 dpi and was approximately 1 to $1.5 \operatorname{logs}$ lower than $P$. syringae pv. tomato DC3000 at 5 to $7 \mathrm{dpi}$ (Fig. 2G). Interestingly, the growth of DB29 was more impaired in seedling leaves (cotyledons) as compared with the population in whole seedlings (Fig. $2 \mathrm{H}$ ). It is tempting to speculate that $\mathrm{COR}$ is required for successful colonization in tomato cotyledons. Thus COR is important for the multiplication, persistence, and disease symptom development of $P$. syringae pv. tomato DC3000 in tomato seedlings, which has not been previously reported.

\section{Use of the tomato seedling assay \\ to identify host signaling pathways targeted by COR.}

Recent studies suggest that COR has multiple virulence functions. In Arabidopsis for example, it has been demonstrated that COR facilitates the entry of $P$. syringae pv. tomato into foliar tissue by suppressing the closure of stomata (Melotto et al. 2006). COR was also shown to contribute to $P$. syringae pv. tomato DC3000 pathogenicity in Arabidopsis by stimulating auxin levels (Kunkel et al. 2004). However, unlike Arabidopsis, COR has additional roles in virulence that are SA-independent (Uppalapati et al. 2007). Purified COR elicits visible chlorosis on tomato leaves (Palmer and Bender 1996; Uppalapati et al. 2005), which is not observed in Arabidopsis. Interestingly, Thilmony and associates (2006) reported that in Arabidopsis, type III secretion system (T3SS) effectors but not COR were involved in the suppression of the photosynthetic light reaction and genes in the Calvin-Benson cycle. Thus COR may function differently in tomato and Arabidopsis. Using a small set (approximately 500) of unique tomato genes and a genetically undefined COR ${ }^{-}$mutant, Zhao and associates (2003) provided evidence for the COR-dependent suppression of SA-mediated defense responses during pathogenesis in tomato. Furthermore, using purified COR on tomato leaves, we have shown that COR targets multiple phytohormone pathways and also targets the JA pathway in tomato (Uppalapati et al. 2005). It is important to note that our previous study (Uppalapati et al. 2005) was conducted in the absence of the pathogen; thus, we could have missed several processes that are related to pathogenesis. For example, suppression of the SA pathway by COR was not observed when using purified COR (Uppalapati et al. 2005). However, a comprehensive list of tomato signaling pathways targeted by $P$. syringae pv. tomato DC3000 in a COR-dependent manner is not available, and the precise mode of action of COR during pathogenesis remains unclear.

To identify novel signaling pathways targeted by COR, we compared the expression profiles of tomato seedlings inoculated with $P$. syringae pv. tomato DC3000 and DB29 $24 \mathrm{~h}$ postinoculation (hpi) using TOM1 (Alba et al. 2004). The TOM1 cDNA microarray contains 12,899 expressed sequence tag (EST) clones representing 8,500 independent tomato genes (Alba et al. 2004). When a twofold cutoff $(P<0.05)$ relative to the gene expression in DB29-inoculated tissues was used, 774 and 424 genes belonging to different functional groups were identified as induced or repressed, respectively, in a CORdependent manner. A complete list of COR-regulated genes is presented as supplementary data (Tables S1 to S3). Here, we discuss some of the genes that were previously shown to be regulated in foliar assays and other COR-regulated genes that have not been previously identified in tomato or Arabidopsis.

In the current study, we used a recently developed MAPMAN ontology conversion of the TOM1 microarray (Thimm et al. 2004; Urbanczyk-Wochniak et al. 2006) to obtain a global view of COR-regulated genes in various metabolic processes (Fig. 3; Supplementary Figs. S2 and S3). It is noteworthy that several genes involved in amino-acid metabolism were differentially expressed in response to COR (Fig. 3A, amino acids). Interestingly, genes involved in the catabolism of the serine-glycine group of amino acids were down-regulated, whereas several genes involved in biosynthesis of the same group of amino acids were strongly induced by COR (Fig. 3A, amino acids). Similarly, several genes involved in the biosynthesis of $\mathrm{N}_{2}$-transport amino acids belonging to the glutamineasparagine family were induced by COR (Fig. 3A, amino acids). Bashan and associates (1986) demonstrated that $P$. syringae pv. tomato can utilize free amino acids as a nitrogen source and can grow well in serine, glycine, threonine, or glutamine. Furthermore, during pathogenesis, tomato leaves accumulate high levels of asparagine and glutamine, and the application of asparagine or glutamine to tomato leaves increased disease severity (Bashan et al. 1986). Interestingly, our microarray results provided a role for COR in regulating amino-acid metabolism during pathogenesis. When considered in the context of the physiological studies conducted by Bashan and associates (1986), we propose that COR-induced amino-acid changes help the pathogen multiply to higher levels and contribute to symptom development in tomato.

A MAPMAN conversion of TOM1 data also allowed a direct comparison of results obtained in tomato with COR responses reported in Arabidopsis (Thilmony et al. 2006). Unlike Arabidopsis, many genes involved in the photosynthetic light reaction, Calvin-Benson cycle, and tetrapyrrole synthesis were strongly repressed by COR in tomato (Fig. 3A; Supplementary Table $\mathrm{S} 2$ ). In tomato, several genes involved in reactive oxygen species (ROS) homeostasis were strongly induced by COR (Fig. $3 \mathrm{~A}$; genes numbered 1 through 7). One of the hallmarks of bacterial speck is the formation of necrotic lesions surrounded by prominent chlorotic halos (Bender et al. 1987; Gnanamanickam et al. 1982). However, the significance of COR-induced chlorosis in disease development is not known. Based on the differential expression of Calvin-Benson cycle genes and ROS, it is 

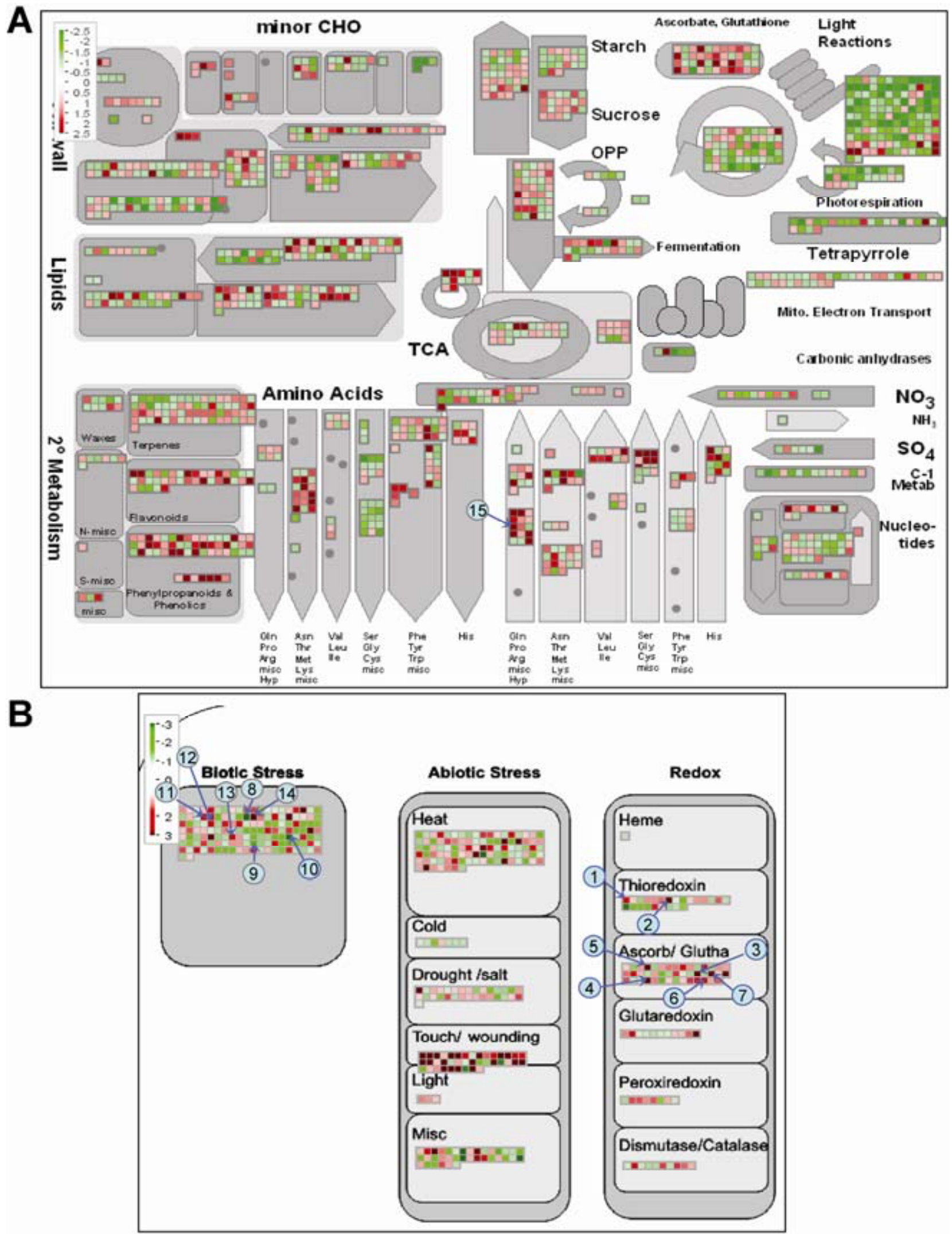

Fig. 3. MAPMAN illustration of TOM1 microarray data showing the genes involved in different metabolic processes targeted by coronatine (COR). A, Global transcriptional changes in tomato seedlings inoculated by flooding with Pseudomonas syringae pv. tomato DC3000 and COR ${ }^{-}$mutant DB29 were compared in order to identify COR-regulated genes. B, A MAPMAN illustration showing stress-related genes. Genes that are numbered include: $1=$ thioredoxin (TOM1 ID: 1.1.9.2), 2 = tetratrocoredoxin (TOM1 ID: 3.1.10.4), 3 = dehydroascorbate reductase (TOM1 ID: 4.1.10.19), $4=$ glutathione reductase (TOM1 ID: 6.4.6.14), $5=$ an unknown protein (TOM1 ID: 2.3.13.16), $6=$ glutathione peroxidase (TOM1 ID: 5.4.11.13), 7 = L-ascorbate oxidase (TOM1 ID: 4.3.15.21), 8 = pathogenesis-related (PR)-1 (TOM1 ID: 2.3.10.15); 9 = PR-23 (TOM1 ID: 7.2.20.16); 10 = a PR-5-like protein (TOM1 ID: 6.3.1.19); 11 = a PR protein (TOM1 ID: 2.2.14.17), 12 = a disease-resistance protein (TOM1 ID: 3.2.17.12), 13 = a systemin precursor (TOM1 ID: 5.4.9.7); and 14 = a hypothetical protein (TOM1 ID: 2.3.11.13). Red indicates upregulation, and green downregulation. 
tempting to speculate that COR-induced effects on photosynthesis and the Calvin cycle may lead to ROS generation and promote cell death in a COR-dependent manner. In support of this, preliminary results suggest that COR-induced effects on photosynthetic machinery result in the accumulation of ROS in alight-dependent manner, which leads to necrosis in bacterial speck disease of tomato (data not shown).

\section{COR targets multiple phytohormone pathways in tomato seedlings.}

To gain a better understanding of tomato seedling responses to $P$. syringae pv. tomato, the effects of COR on phytohormone pathways was analyzed. In general, COR targeted multiple phytohormone pathways (JA, ethylene [ET], auxin) in tomato seedlings, which is similar to previous reports (Thilmony et al. 2006; Uppalapati et al. 2005; Zhao et al. 2003). Our transcriptome analysis identified both known and novel genes associated with COR. In a COR-dependent manner, P. syringae pv. tomato DC3000 induced genes involved in JA biosynthesis, including lipoxygenase $(L O X D)$, allene oxide cyclase $(A O C)$, and 12-oxophytodienoate reductase 3 (OPR3). Furthermore, many JA and wound-inducible genes, such as proteinase inhibitor $(P I)$ and polyphenol oxidase $(P P O)$ were also up-regulated in a COR-dependent manner during pathogenesis in tomato seedlings. Northern blot analyses further confirmed that the expression of JA pathway genes ( $L O X D, O P R 3$ and $P I-I I)$ were induced in seedlings inoculated with $P$. syringae pv. tomato DC3000 within 12 hpi but not in seedlings inoculated with DB29 (Fig. 4A).

Threonine deaminase $(T D)$, a gene involved in the biosynthesis of isoleucine (Ile), was strongly induced by $P$. syringae pv. tomato DC3000 in a COR-dependent manner (Fig. 4A). A recent study has shown that $T D$-induced Ile forms conjugates with JA, resulting in JA-Ile (Kang et al. 2006). Previously, a jarl mutant of Arabidopsis (jasmonate resistance 1, which was unresponsive to JA-induced root inhibition) showed altered physiological responses to purified COR but the same level of susceptibility to $P$. syringae pv. tomato DC3000 as wild-type plants (Laurie-Berry et al. 2006). However, COR is shown to mimic JA-Ile in bioassays (Krumm et al. 1995). It remains unclear whether COR-induced TD was responsible for the JAIle-like activity.

Recently, AtJAZ1 and SIJAZ1 (Thines et al. 2007) and AtJAZ3 (Chini et al. 2007), which belong to the JAZ protein family, were identified as repressors of jasmonate-responsive tran-
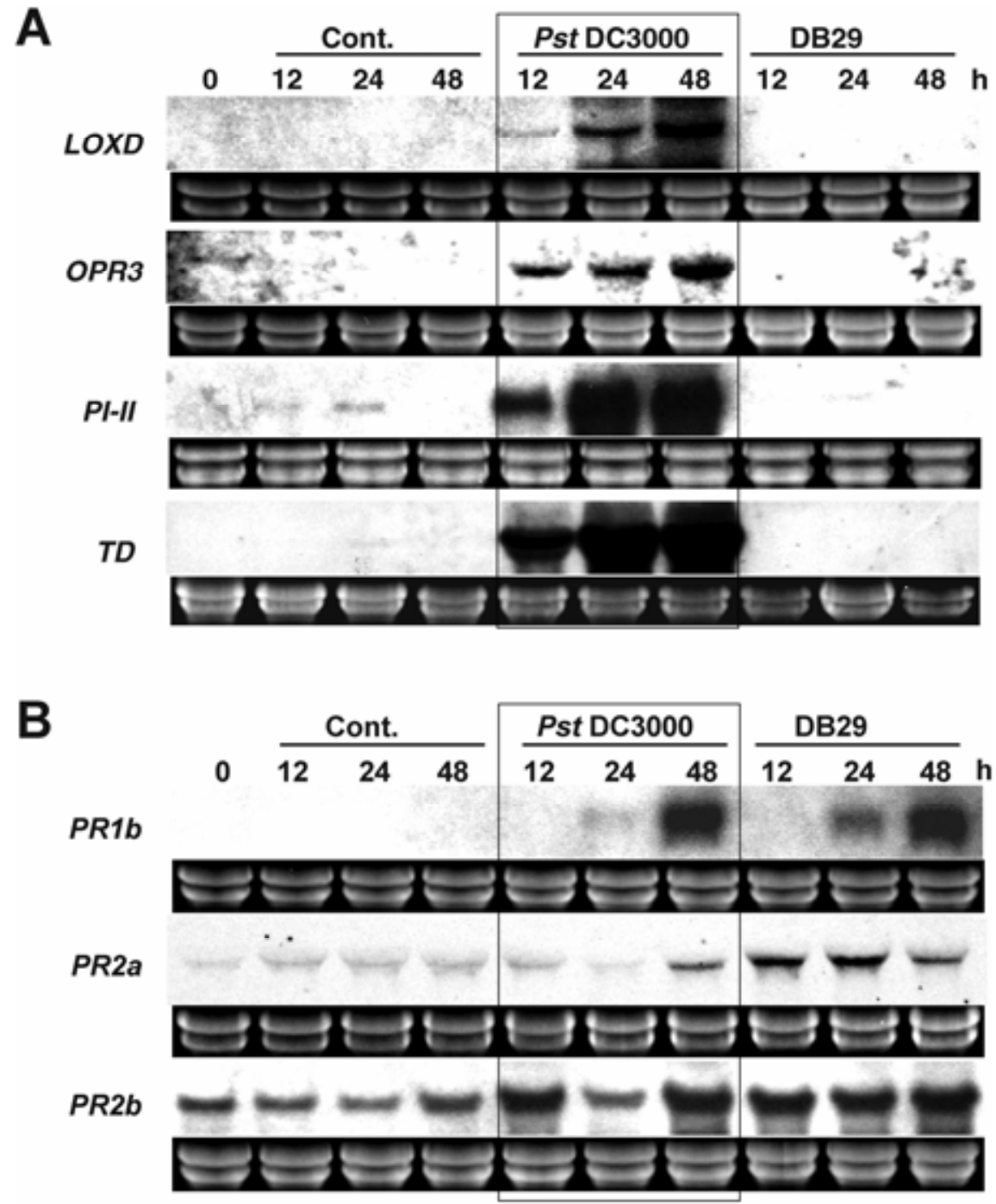

Fig. 4. Expression profiles of jasmonic acid (JA)-inducible and salicylic acid (SA)-dependent genes in tomato seedlings in response to Pseudomonas syringae pv. tomato DC3000 (Pst DC3000), COR ${ }^{-}$mutant DB29, or water as a control (Cont.). A, Expression profiles are presented for JA-inducible lipoxygenase $(L O X D)$, 12-oxophytodienoate reductase $3(O P R 3)$, proteinase inhibitor II (PI-II), and threonine deaminase (TD). B, Expression profiles are presented for SA-dependent pathogenesis-related genes $1 \mathrm{~b}(P R 1 b), 2 \mathrm{a}(P R 2 a)$, and $2 \mathrm{~b}(P R 2 b)$. Total RNA (10 $\mu$ g) was loaded, and the ethidium bromide-staining of rRNA shows equal quality and quantity of each samples. 
scription factors in Arabidopsis and tomato, respectively. Although SIJAZ1 is not represented in the TOM1 microarray, our transcriptome analysis identified a COR-induced tomato clone, cLER1I12, which showed high homology to AtJAZ2. Although the functional analysis of SIJAZ2 in COR-induced responses has not been conducted, our results show the potential of TOM1 arrays in identifying new targets for COR.
COR functions to suppress SA-mediated defense in tomato seedlings.

We further investigated whether tomato seedlings respond to $P$. syringae pv. tomato DC3000 by mounting SA defense responses and whether COR functions as a suppressor of SA responses in seedlings. In tomato seedlings, COR downregulated several genes involved in biotic stress and defense, including

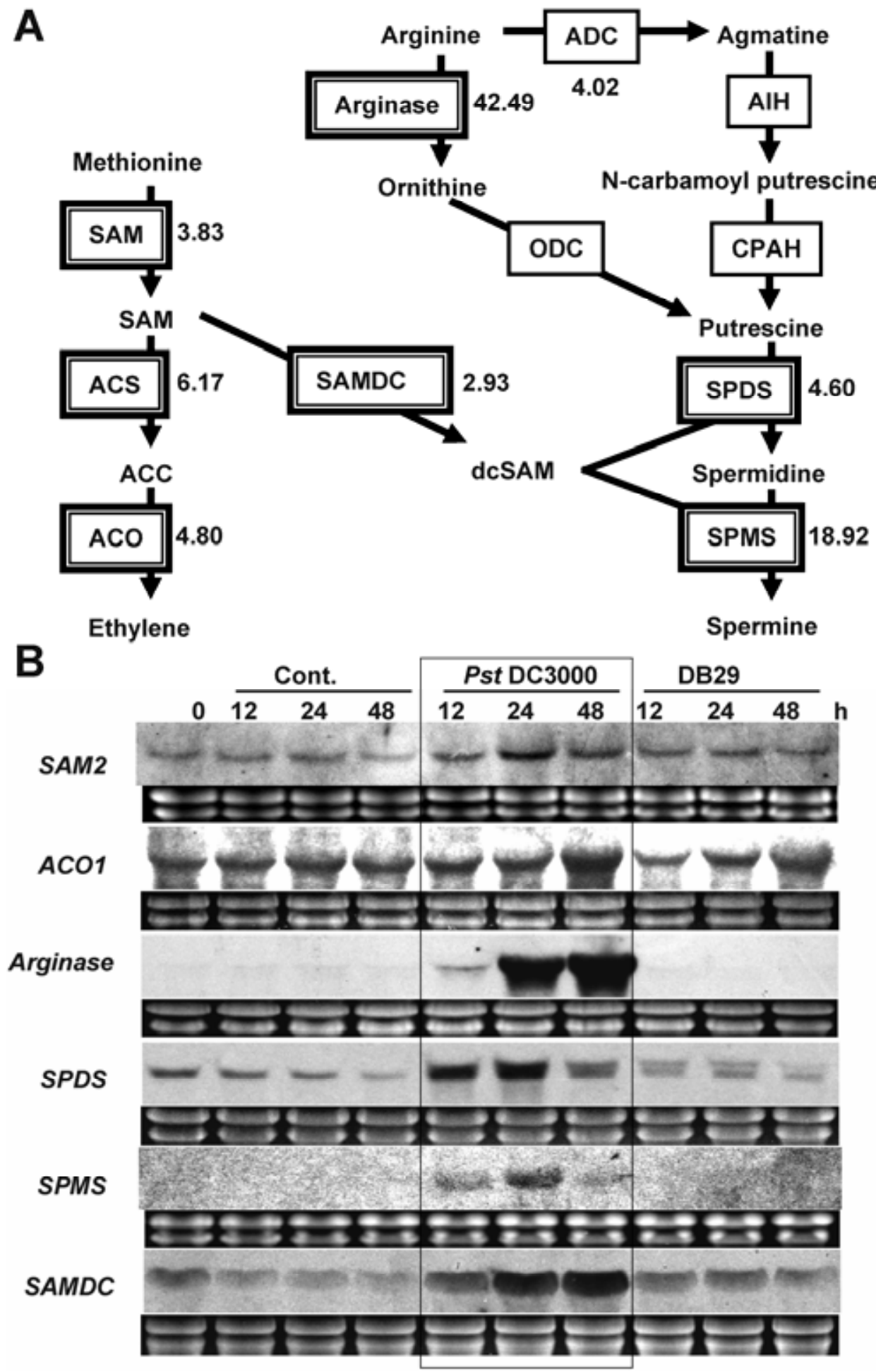

Fig. 5. Coronatine (COR) induces genes involved in polyamine biosynthesis during pathogenesis. A, Overview of ethylene and polyamine biosynthesis. The values represent the fold changes from TOM1 expression data ( $\log _{2}$ value). B, Expression profiles of selected genes in tomato seedlings in response to Pseudomonas syringae pv. tomato DC3000, COR ${ }^{-}$mutant DB29, or water as a control (Cont.). Expression profiles using Northern blot analysis are presented for $S$-adenosylmethionine synthetase 2 (SAM2), 1-aminocyclopropane-1-carboxylate oxidase (ACO1), arginase, spermidine synthase (SPDS), spermine synthase $(S P M S)$, and $S$-adenosylmethionine decarboxylase (SAMDC). Total RNA $(10 \mu \mathrm{g})$ was loaded, and the ethidium bromide-staining of rRNA shows equal quality and quantity of each samples. 

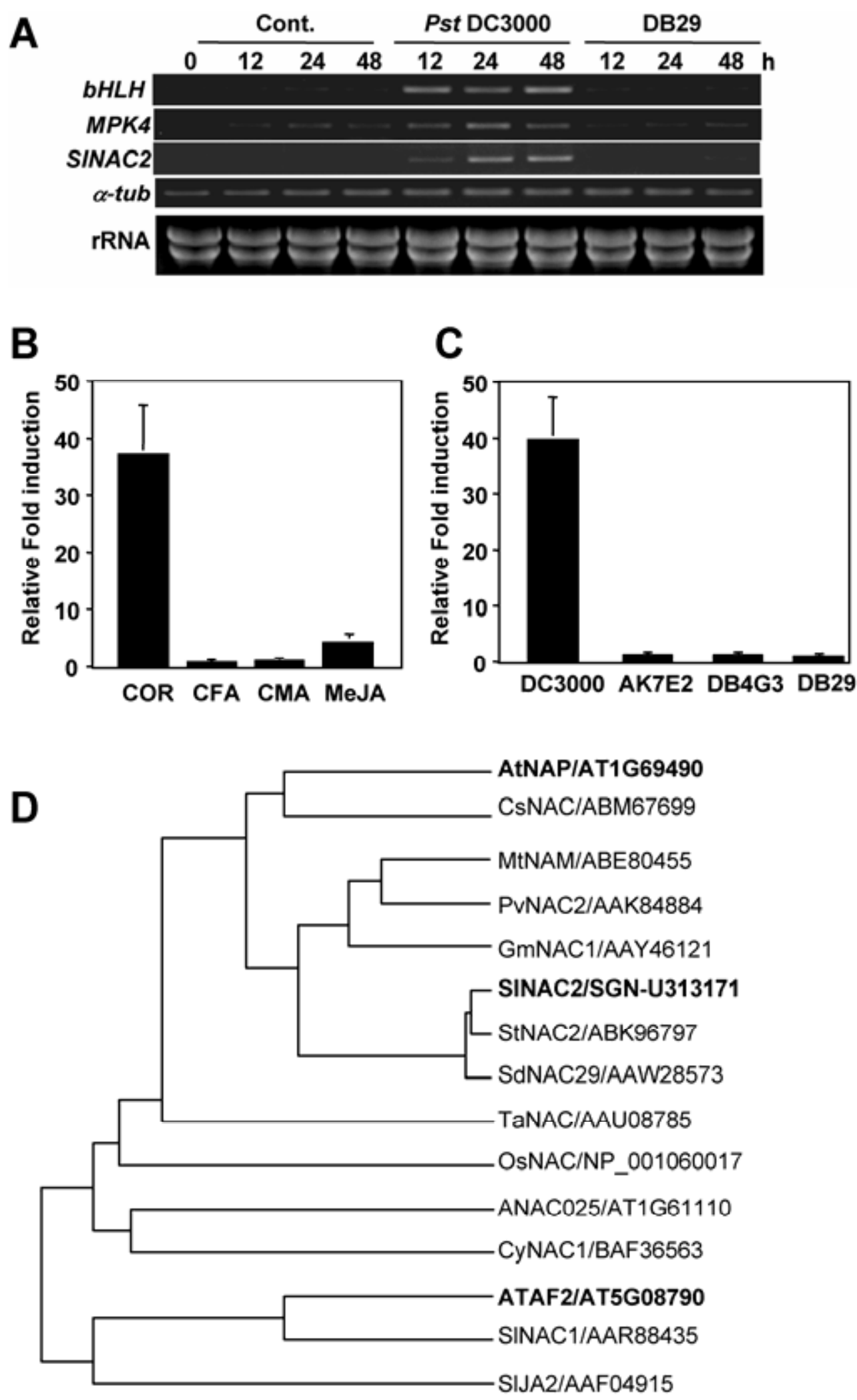

Fig. 6. Coronatine (COR) induces SINAC2 and other genes belonging to jasmonic acid and salicylic acid pathways. A, Expression profiles of bHLH-type transcription factor $(b H L H)$, MAP kinase 4 (MPK4) gene, and a NAC-type transcription factor (SlNAC2) in tomato seedling leaves flood-inoculated with Pseudomonas syringae pv. tomato DC3000 or the $\mathrm{COR}^{-}$mutant DB29. The expression profile of $\alpha$-tubulin and ethidium bromide-staining of rRNA were used to show the quality and quantity of cDNA and RNA, respectively. B, Fold induction ( $24 \mathrm{~h}$ posttreatment [hpt]) relative to the water controls of SlNAC2 in tomato seedling leaves treated individually with 200 pmol of COR, coronafacic acid (CFA), coronamic acid (CMA), or methyl jasmonic acid (MeJA). C, Fold induction (24 hpt) relative to the water controls of SINAC2 (24 hpi) in tomato seedling leaves flood-inoculated individually with $P$. syringae pv. tomato DC3000, $\mathrm{CMA}^{-}$(AK7E2), CFA-(DB4G3), or the $\mathrm{CMA}^{-} \mathrm{CFA}^{-}$(DB29) mutant. D, Phylogenetic tree based on the amino-acid sequences of NAC domain proteins of tomato NAC (LeNAC/SGN-U313171, named as SINAC2). Phylogenetic tree was constructed using the UPGMA program of Genetyx-Mac (Software Development, Tokyo). The names of proteins are indicated at the right of the tree with the accession number from the protein database or code number from the genome database. 
11 pathogenesis-related (PR) genes (e.g. PR1, PR2, PR3, PR5, and $P R 23$; Fig. 3B, numbers 8,9 , and 10). Interestingly, several genes encoding biotic stress-related proteins, including two unknown PR-related proteins (Fig. 3A; numbers 11 and 12), systemin (Fig. 3A; number 13), and a hypothetical protein (Fig. $3 \mathrm{~A}$; number 14), were induced by COR. To confirm the microarray results and follow the kinetics of $P R$ gene expression, we monitored the expression of PRla, PR2a, and $P R 2 b$ in seedlings inoculated with $P$. syringae pv. tomato DC3000 and DB29. The results clearly demonstrated that $P$. syringae pv. tomato DC3000 suppresses the expression of $P R$ genes during pathogenesis relative to DB29 (Fig. 4B). The results further demonstrated differential expression patterns of $P R$ genes during disease development (Fig. 4B). For example, the expression of $P R 1 b$ and $P R 2 a$ was strongly suppressed for the first $24 \mathrm{hpi}$ in tissues inoculated with $P$. syringae pv. tomato DC3000 but not in tissues inoculated with the COR ${ }^{-}$mutant DB29 (Fig. 4B). However, the expression of $P R 2 b$ was initially (12 hpi) induced after inoculation with either P. syringae pv. tomato DC3000 or DB29 (Fig. 4B). Interestingly, at $24 \mathrm{hpi}$, the COR-producing strain DC3000 suppressed the expression of a basic $P R$ gene, $P R 2 b$ (Fig. 4B). Basic $P R$ genes are generally induced by ET signaling (Brederode et al. 1991). However, Zhao and associates (2003) have shown that both the T3SS and COR suppress $P R 2 b$. Taken together, these results suggest a complex cross-talk of ET and JA-mediated signaling pathways during bacterial speck disease development in tomato.

\section{COR differentially regulates genes involved in polyamine metabolism.}

One novel finding of the present work is that $P$. syringae pv. tomato DC3000 targets polyamine biosynthesis in a COR-dependent manner during pathogenesis. The expression of arginase, an enzyme potentially involved in polyamine (putrescine) biosynthesis via ornithine (Fig. 5A) was significantly induced in seedling tissues inoculated with $P$. syringae pv. tomato DC3000 but not DB29 (Fig. 5A and B). Furthermore, genes involved in the biosynthesis of spermidine, spermine, and putrescine, including $S$-adenosylmethionine decarboxylase (SAMDC), spermidine synthase (SPDS) (Fig. 5A), spermine synthase (SPMS) (Fig. 5B) arginine decarboxylase and arginase (Fig. 3A, number 15) were strongly induced in a COR-dependent manner during pathogenesis. These results indicate that COR from $P$. syringae pv. tomato DC3000 induces polyamine biosynthetic genes.

The role of polyamines in compatible plant-pathogen interaction is unclear. Previously, Chen and associates (2004) demonstrated the induction of arginase in response to COR and $P$. syringae pv. tomato DC3000 infection in tomato. Arginase is an important enzyme in polyamine biosynthesis, and therefore, Chen and associates (2004) speculated a role for polyamines in wound healing. Our results on expression of $S A M D C, S P D S$, $S P M S$, and arginine decarboxylase (Fig. 5) present further evidence for polyamine biosynthesis during pathogenesis. Interestingly, during plant interactions with biotrophic fungal pathogens, polyamines were suggested to play a role in maintaining metabolic activity or juvenility of plant tissues surrounding infection sites (Walters 2003). These metabolically active sites can then act as a source of nutrients for biotrophs. Based on our results, it is tempting to speculate that COR may play an important role in maintaining metabolically active cells in areas surrounding the infection site by inducing polyamine levels during the early stages of pathogenesis.

\section{COR modulates expression of SINAC2 and} regulatory genes in the $\mathrm{SA}$ and JA pathways.

Microarray analysis revealed that COR from $P$. syringae pv. tomato DC3000 upregulates several genes that function in cross-talk between the JA-ET-SA and JA-ET signaling pathways (Anderson et al. 2004; Lorenzo et al. 2004). These genes included LeMPK4, LebHLH (Fig. 6A), and LeMYB4. Interestingly, AtMPK4 has been implicated in negative regulation of SA-mediated defense responses in Arabidopsis (Petersen et al. 2000); whereas, the homologs of LebHLH in Arabidopsis (AtbHLH, AtMYC2/JIN1) act as key regulators of JA and ETSA cross-talk. AtMYC2/JIN1 mutants are known to be resistant to biotrophic pathogens (Laurie-Berry et al. 2006; Nickstadt et al. 2004). Based on these results, it is tempting to speculate that the COR-induced tomato ortholog of AtMPK4 and AtMYC2/ JIN1 may function to suppress SA-mediated defense responses during P. syringae pv. tomato DC3000 pathogenesis in tomato.

Furthermore, we identified SINAC2, a NAC domain transcription factor (TF) that is specifically induced by COR (Fig. 6). To further test the specificity of SINAC2 expression, we conducted a more sensitive real-time reverse transcriptasequantitative polymerase chain reaction (RT-qPCR) analysis (Fig. 6B and C). Interestingly, at equimolar concentrations (200 pmole), COR induced a fivefold higher induction of SINAC2 than methyl jasmonic acid (MeJA) (Fig. 6B). Furthermore, CFA and CMA (the components of COR) had no significant effect on SINAC2 expression (Fig. 6B). Similarly, only the wild-type $P$. syringae pv. tomato DC3000 but not the $\mathrm{CMA}^{-}$(AK7E2), $\mathrm{CFA}^{-}$(DB4G3), or $\mathrm{CFA}^{-}$(DB29) mutants induced the expression of SINAC2 (Fig. 6C), suggesting that SINAC2 expression is specifically regulated by COR during pathogenesis.

NAC domain TF are widespread in plant genomes, and more than 160 NAC domain-containing TF have been identified in Arabidopsis and rice (Olsen et al. 2005). Several NAC TF are implicated in biotic stress and hormone responses (Olsen et al. 2005). For example, ATAF2 is shown to act as a repressor of $P R$ genes in Arabidopsis (Delessert et al. 2005) and HvNAC6 is involved in fungal resistance (Jensen et al. 2007). Phylogenetic analysis revealed that SINAC2 is a unique NAC-domain TF and belongs to a different subfamily from S1JA2 (Solanum lycopersicum JA2, a JA-inducible protein) and ATAF2 (Fig. 6D). However, SINAC2 showed a close phylogenetic relationship with AtNAP, an Arabidopsis gene encoding NAC family TF (Fig. 6D) (Guo and Gan 2006). Interestingly, AtNAP was shown to be specifically induced during senescence but not by other phytohormones including MeJA (Guo and Gan 2006). Previously, in a comparative study of COR- and MeJAinduced responses on tomato leaves, we demonstrated that MeJA $(100 \mu \mathrm{M})$ does not elicit chlorosis at the application site and induced a strong expression of SINAC2 on tomato leaves (Uppalapati et al. 2005). Taken together with the results presented in this study (Fig. 6), it is tempting to speculate that COR-induced SINAC2 may play an important role in the severe chlorotic phenotype induced by COR but not by MeJA on tomato leaves.

\section{Conclusions.}

Foliar assays have been used to screen for host resistance of tomato to $P$. syringae pv. tomato (Pilowsky and Zutra 1982; Salmeron et al. 1994) and for isolating P. syringae pv. tomato mutants with impaired virulence (Cuppels 1986). Boch and associates (2002) and Brooks and associates (2004) screened transposon mutants of $P$. syringae pv. tomato DC3000 for impaired virulence on Arabidopsis using a dip-inoculation method. Although these methods for assessing the virulence of $P$. syringae have been established, they are not rapid, highthroughput methods that facilitate the screening of large numbers of mutants. Thus the aim of this work was to develop a seedling assay that could be used in both virulence screens and in gene expression studies. To our knowledge, our assay is a 
novel approach to study $P$. syringae pv. tomato DC3000 infection of tomato seedlings, and the assay parameters were optimized to improve efficiency, consistency, and reproducibility. The method described here can be effectively used for highthroughput screens and has several advantages over foliar assays, including a shorter growth and incubation period (5 weeks vs. 7 to 10 days), ease of inoculation and handling (4 to $5 \mathrm{~min}$ vs. 20 to $30 \mathrm{~min}$ per sample), and rapid generation of larger sample sizes per experiment. Tornero and Dangl (2001) previously described a high-throughput bacterial quantification method using young (14-day-old) plants grown in pots. Our assay is performed on seedlings in petri dishes, an approach that requires less labor, space, and maintenance than plants grown in pots. In our hands, high-throughput estimation of bacterial populations by shaking the seedlings in a buffer, as described by Tornero and Dangl (2001) for Arabidopsis, was less reliable for tomato seedlings (data not shown). Homogenization of the tomato seedling was required for reliable measurement of bacteria in the apoplast (Figs. $1 \mathrm{C}$ and $2 \mathrm{G}$ and $\mathrm{H}$ ). The method we adapted to homogenize seedlings in an Eppendorf tube using a motorized pestle also reduced labor and saved time. One of the advantages of the seedling assay over foliar assays is the low experimental variation between replicate experiments (Fig. 2G and H). Furthermore, when our seedling assay is combined with the recently reported luminescence quantification assay of luxCDABE-tagged $P$. syringae (Fan et al. 2007) or GFPuv-labeled bacteria (Wang et al. 2007), it may be possible to identify virulence phenotypes that have subtle effects.

In conclusion, our assay is a novel approach to study $P$. syringae pv. tomato DC3000 infection of seedlings and to dissect interactions with tomato. We have established that the seedling assay could be used effectively for the identification of genes involved in pathogenesis by using some of the wellcharacterized virulence mutants. Furthermore, we have demonstrated that COR is required for virulence in tomato seedlings. Using seedling assays and a MAPMAN display of TOM1 microarrays data, we identified additional host pathways targeted by COR in tomato that have not been previously reported.

\section{MATERIALS AND METHODS}

Plant material, bacterial isolates, and bacterial inoculation.

Tomato seeds of Solanum lycopersicum cv. Glamour were obtained from Stokes Seeds, Inc. (Buffalo, NY, U.S.A.). Seedlings were grown on MS medium ( $0.8 \%$ agar) with Gamborg vitamins (PhytoTechnologies Laboratories, Shawnee Mission, KS, U.S.A.). After 4 days of germination in darkness at $28^{\circ} \mathrm{C}$, usually seedlings had 2- to 3-cm-long hypocotyls and two seedling leaves (cotyledons). In general, a period of 4 days was sufficient to obtain seedlings suitable for inoculation; however, it is important to mention that the incubation period could vary depending on the cultivar and conditions used.

P. syringae pv. tomato DC3000 and mutants AK7E2 $\left(\mathrm{CFA}^{+}\right.$ $\mathrm{CMA}^{-}$; cmaA::Tn5), DB4G3 (CFA ${ }^{-} \mathrm{CMA}^{+}$; cfa6::Tn5), and DB29 (CFA ${ }^{-} \mathrm{CMA}^{-}$; cfa6-cmaA double mutant; Brooks et al. 2004) were grown at $28^{\circ} \mathrm{C}$ on King's B liquid medium (KB) (King et al. 1954) for 36 to $48 \mathrm{~h}$. Antibiotics were added to media in the following concentrations $(\mu \mathrm{g} / \mathrm{ml})$ : rifampicin, 100; kanamycin, 25; and spectinomycin, 25. Prior to inoculation, bacteria were suspended in $1 \mathrm{ml}$ of sterile distilled $\mathrm{H}_{2} \mathrm{O}$. To study the effect of inoculum concentration on symptom development, three different concentrations (optical density at $600 \mathrm{~nm}\left[\mathrm{OD}_{600}\right]=0.01,0.1$ and 1.0$)$ of $P$. syringae pv. tomato DC3000 were used.

Tomato seedlings were inoculated by a flooding method in which the MS agar plate was flooded with bacterial cells as described below. The bacterial suspension $\left(\mathrm{OD}_{600}=0.1\right)$ consisted of sterile distilled $\mathrm{H}_{2} \mathrm{O}$ containing $0.025 \%$ Silwet L-77 (OSi Specialties, Inc., Danbury, CT, U.S.A.). To achieve uniform inoculation, the bacterial suspension was dispensed into petri dishes until the seedlings were completely submerged and the seedlings were exposed to bacterial cells for 2 to $3 \mathrm{~min}$ with gentle mixing. After the inoculum was discarded, petri dishes containing inoculated seedlings were sealed with parafilm and were incubated at $24^{\circ} \mathrm{C}$ with light intensity of 100 to $150 \mu \mathrm{E} \mathrm{m}^{-2} \mathrm{~s}^{-1}$ and a $12 \mathrm{~h}$-light, 12-h dark photoperiod. Seedlings were observed at $1,2,4$, and 7 dpi for symptom development. Another set of seedlings was flooded with sterile water that served as mock control. In each experiment, 10 to 15 seedlings were evaluated, and each experiment was repeated at least three times.

Bacterial growth in seedlings was measured by determining the internal bacterial population at several timepoints after inoculation. Prior to sampling, seedlings were surface-sterilized with $15 \% \mathrm{H}_{2} \mathrm{O}_{2}$ for 3 min to eliminate epiphytic bacteria and then were washed with sterile distilled $\mathrm{H}_{2} \mathrm{O}$. Seedlings were then homogenized in sterile distilled $\mathrm{H}_{2} \mathrm{O}$, and serial dilutions were plated onto $\mathrm{KB}$ medium containing the appropriate antibiotics. The bacterial population at $0 \mathrm{dpi}$ was estimated from seedlings harvested $1 \mathrm{hpi}$. It is important to note that $\mathrm{H}_{2} \mathrm{O}_{2}$ may not kill all the epiphytic bacteria, and therefore, our internal population counts might include a small number of epiphytic bacteria.

\section{RNA extraction and microarray analysis.}

Total RNA isolation, purification, and TOM1 microarray analyses were done using the methods described earlier (Uppalapati et al. 2005). Briefly, total RNA was purified from tomato seedlings inoculated with $P$. syringae $\mathrm{pv}$. tomato DC3000 and DB29 for $24 \mathrm{~h}$, using TRIzol Reagent (Invitrogen, Carlsbad, CA, U.S.A.) according to the manufacturer's instructions. Total RNA was extracted from 10 inoculated seedlings, and following isolation, the total RNAs were pooled to represent one biological replicate. Three independent experiments were carried out on three different days. Total RNA was treated with DNase I (Invitrogen) to eliminate genomic DNA and was further concentrated using Microcon YM100 filters (Millipore Corp., Bedford, MA, U.S.A.).

Approximately $50 \mu \mathrm{g}$ of denatured total RNA from three biological replicates was used to synthesize cDNA with an oligo $d(T)$ primer, which was tagged with either Cy3- or Cy5specific 3DNA capture sequence (Genisphere Inc., Hartfield, PA, U.S.A.). Total RNA (50 $\mu \mathrm{g})$ and tagged oligo d(T) $(1 \mu \mathrm{l})$ primer were mixed in a final volume of $10 \mu \mathrm{l}$ with RNase-free water, were heat-denatured at $80^{\circ} \mathrm{C}$ for $10 \mathrm{~min}$, and were cooled on ice. For reverse transcription, master mix $(8 \mu \mathrm{l})$ containing $2 \mu \mathrm{l}$ of 10× Superscript RT buffer (Invitrogen), $1 \mu \mathrm{l}$ of RNase-OUT (Invitrogen), $1 \mu \mathrm{l}$ of $10 \mathrm{mM}$ dNTP (Invitrogen), 2 $\mu \mathrm{l}$ of $0.1 \mathrm{M}$ dithiothreitol (Invitrogen), and $2 \mu \mathrm{l}$ of $25 \mathrm{mM}$ $\mathrm{MgCl}_{2}$ (Invitrogen) was prepared and mixed with denatured total RNA and oligo d(T). Each sample was heated at $42^{\circ} \mathrm{C}$ for $3 \mathrm{~min}$, and $2 \mu \mathrm{l}$ of Superscript III RT (Invitrogen) was added. The RT reaction was incubated at $42^{\circ} \mathrm{C}$ for $3 \mathrm{~h}$, was supplemented with $3.5 \mu \mathrm{l}$ of stop solution, containing $0.5 \mathrm{M} \mathrm{NaOH}$ and $50 \mathrm{mM}$ EDTA, and then, was incubated at $65^{\circ} \mathrm{C}$ for 10 min to stop the RT reaction and hydrolyze template RNA. For neutralization of cDNA mix, $5 \mu \mathrm{l}$ of $1 \mathrm{M}$ Tris- $\mathrm{HCl}(\mathrm{pH} 7.5)$ was added and $6.6 \mu \mathrm{l}$ of Cy3- or Cy5-labeled cDNA was used for hybridization.

TOM1 arrays were obtained from the Center for Gene Expression Profiling, Boyce Thompson Institute, Cornell University (Ithaca, NY, U.S.A.). For the hybridization reaction, $6.6 \mu \mathrm{l}$ of tagged cDNA, $1.5 \mu \mathrm{l}$ of salmon sperm DNA at a concentra- 
tion of $1 \mu \mathrm{g} / \mu \mathrm{l}$ (Invitrogen), $2 \mu \mathrm{l}$ of oligo $\mathrm{d}(\mathrm{T})$ blocker (Genisphere), and $1 \mu \mathrm{l}$ of high-end differential enhancer (Genisphere) were added to $41.3 \mu \mathrm{l}$ of high sodium dodecyl sulfate (SDS) hybridization buffer (Genisphere). A total of $60 \mu \mathrm{l}$ of mixture was incubated initially at $80^{\circ} \mathrm{C}$ for $10 \mathrm{~min}$ and then at $60^{\circ} \mathrm{C}$ for $20 \mathrm{~min}$ before applying to prewarmed slides. A cover glass was placed on top of the glass slide to uniformly distribute the hybridization solution. The slides were then incubated at $60^{\circ} \mathrm{C}$ in a water bath for $16 \mathrm{~h}$ in a Corning hybridization chamber (Corning Inc., Acton, MA, U.S.A.). The three posthybridization washes were follows: i) at $60^{\circ} \mathrm{C}$ for $15 \mathrm{~min}$ in $2 \times \mathrm{SSC}(1 \times$ $\mathrm{SSC}$ is $0.15 \mathrm{M} \mathrm{NaCl}$ plus $0.015 \mathrm{M}$ sodium citrate), $0.2 \% \mathrm{SDS}$; ii) at room temperature in $2 \times \mathrm{SSC}$; and iii) at room temperature in $0.2 \times \mathrm{SSC}$. Then, the samples were fixed in $95 \%$ ethanol for $2 \mathrm{~min}$ and were dried by centrifugation at $1,000 \times g$ for 2 min. The hybridized cDNA was incubated with $\mathrm{Cy} 3$ and $\mathrm{Cy} 5$ 3DNA reagent and was incubated for $3 \mathrm{~h}$ as explained above. The slides were washed and dried as described above.

The slides were analyzed with ScanArray 3000 (GSI Lumonics, Billerica, MA, U.S.A.) and the spots were quantified using GenePix Pro 4.0 (Axon Instruments, Inc., Union City, CA, U.S.A.). Preprocessing of data was accomplished using GenePix Autoprocessor. The data was normalized using global locally weighted linear regression normalization (Yang et al. 2002). A candidate list of differentially expressed genes was then generated using a 5\% false discovery rate (FDR) and $>2$ fold change between treatments. We used moderated $t$ statistics and associated $P$ values after FDR in the LIMMA package of the Bioconductor software package. A total of three biological replicate experiments were conducted for each samples. In compliance with MIAME guidelines, raw data (before normalization) and normalized data with the mean ratios for COR-regulated genes, along with a sample of the scanned image, are presented in Supplementary Figures S4 and S5. Furthermore, all the data will be submitted to the Tomato expression database (Cornell University).

\section{MAPMAN conversion of TOM1 microarray data.}

The average mean ratios of normalized data were imported into the MAPMAN software, which converts the data values to a false-color scale and associates a gene to a relevant metabolic function and places them on an appropriate metabolic pathway (Thimm et al. 2004; Usadel et al. 2005). The overview figures and functional categorization of COR-regulated genes were prepared using mapping file version Ses_TOM1 Sep06 as described (Urbanczyk-Wochniak et al. 2006).

\section{Northern blot, semiquantitative RT-PCR, and real-time qPCR analyses.}

Total RNA was purified from tomato seedling leaves treated with water (control) or inoculated with $P$. syringae pv. tomato DC3000 or DB29. Total RNA was extracted using TRIzol (Invitrogen), and 15 treated or inoculated seedling leaves were pooled to represent one biological replicate. Three independent experiments were carried out on three different days. Total RNA $(10 \mu \mathrm{g})$ was denatured and fractionated by electrophoresis on a $1 \%$ agarose gel and, then, was blotted onto nylon membranes (Amersham BioScience, Uppsala, Sweden). Digoxigenin (DIG)-labeled DNA probes were made with DIG PCR labeling mix (Boehringer Mannheim, Mannheim, Germany), using gene-specific forward and reverse primer sets. Hybridization was performed at $65^{\circ} \mathrm{C}$ overnight in a solution containing $50 \mathrm{mM}$ Church buffer (pH. 7.2) (Church and Gilbert 1984), 5× SSC, 0.1\% laurylsarcosine, 7\% SDS (wt/vol), and $2 \%$ blocking solution (Boehringer Mannheim). Final washes were at $65^{\circ} \mathrm{C}$ in a solution containing $0.5 \times \mathrm{SSC}$ and $0.1 \%$ SDS. Hybridized mRNAs were detected with anti-
DIG antibody conjugated with alkaline phosphatase (Boehringer Mannheim) and its chemiluminescent substrate CDPStar (Boehringer Mannheim).

Semiquantitative RT-PCR was conducted with cDNA generated using methods described previously (Uppalapati et al. 2005). For semiquantitative RT-PCR, $1 \mu \mathrm{l}$ of first-strand cDNA (diluted 1:50 in reaction buffer) was amplified using Taq DNA polymerase (Promega). To check for equal amounts of cDNA in each reaction, PCR was performed with primers specific for the gene encoding $\alpha$-tubulin 4 (Mysore et al. 2002).

SINAC2 was quantified using real-time qPCR, based on the primers designed after the EST information on TOM1, using methods described previously (Mysore et al. 2002; Uppalapati et al. 2005). Melt-curve analysis was performed to monitor primer-dimer formation and to check amplification of genespecific products. The average threshold cycle $\left(\mathrm{C}_{\mathrm{T}}\right)$ values, calculated from triplicate samples, were used to determine the fold expression relative to the controls. Primers specific for $\alpha$ tubulin 4 were used to normalize small differences in template amounts. Data analysis including normalization and standard deviations were calculated using Gene Expression Macro, ver 1.1 (Bio-Rad, Philadelphia) with the algorithms described by Vandesompele and associates (2002). Data quantification and analysis was performed using iCycler software (ver. 3.06.6070) and Gene Expression Macro (ver 1.1) (Bio-Rad). Average $C_{T}$ values calculated from triplicate samples were used to determine the fold expression relative to the controls. Primers specific for $\alpha$-tubulin 4 were used to normalize small differences in template amounts.

\section{ACKNOWLEDGMENTS}

We thank J. Murray and M. Tadege for reviewing the manuscript. C. Bender acknowledges support from the National Science Foundation (NSF) (IOB-0620469) and the Oklahoma Agricultural Experiment Station. K. Mysore acknowledges support from the Noble Foundation, and Y. Ishiga acknowledges postdoctoral support from the Japan Society for the Promotion of Science (JSPS). The Oklahoma State University Microarray Core Facility was supported by grants from the NSF (EOS-0132534) and the National Institute of Health (1P20RR16478-02 and 5P20RR15564-03).

\section{LITERATURE CITED}

Alba, R., Fei, Z., Payton, P., Liu, Y., Moore, S. L., Debbie, P., Cohn, J., D’Ascenzo, M., Gordon, J. S., Rose, J. K., Martin, G., Tanksley, S. D., Bouzayen, M., Jahn, M. M., and Giovannoni, J. 2004. ESTs, cDNA microarrays, and gene expression profiling: Tools for dissecting plant physiology and development. Plant J. 39:697-714.

Anderson, J. P., Badruzsaufari, E., Schenk, P. M., Manners, J. M., Desmond, O. J., Ehlert, C., Maclean, D. J., Ebert, P. R., and Kazan, K. 2004. Antagonistic interaction between abscisic acid and jasmonate-ethylene signaling pathways modulates defense gene expression and disease resistance in Arabidopsis. Plant Cell 16:3460-3479.

Bais, H. P., Prithiviraj, B., Jha, A. K., Ausubel, F. M., and Vivanco, J. M. 2005. Mediation of pathogen resistance by exudation of antimicrobials from roots. Nature 434:217-221.

Bashan, Y., Okon, Y., and Henis, Y. 1982. Long-term survival of Pseudomonas syringae pv. tomato and Xanthomonas campestris pv. vesicatoria in tomato and pepper seeds. Phytopathology 72:1143-1144.

Bashan, Y., Okon, Y., and Henis, Y. 1986. A possible role for proteases and deaminases in the development of the symptoms of bacterial speck disease in tomato caused by Pseudomonas syringae pv. tomato. Physiol. Mol. Plant Pathol. 28:15-31.

Bender, C. L., Stone, H. E., Sims, J. J., and Cooksey, D. A. 1987. Reduced pathogen fitness of Pseudomonas syringae pv. tomato Tn5 insertions defective in coronatine production. Physiol. Mol. Plant Pathol. 30:273283.

Bender, C. L., Alarcón-Chaidez, F., and Gross, D. C. 1999. Pseudomonas syringae phytotoxins: Mode of action, regulation and biosynthesis by peptide and polyketide synthetases. Microbiol. Mol. Biol. Rev. 63:266292.

Bent, A. F., Innes, R. W., Ecker, J. R., and Staskawicz. B. J. 1992. Disease development in ethylene-insensitive Arabidopsis thaliana infected with 
virulent and avirulent Pseudomonas and Xanthomonas pathogens. Mol. Plant-Microbe Interact. 5:372-378.

Boch, J., Joardar, V., Gao, L., Robertson, T. L., Lim, M., and Kunkel, B. N. 2002. Identification of Pseudomonas syringae pv. tomato genes induced during infection of Arabidopsis thaliana. Mol. Microbiol. 44:73-88.

Brederode, F. T., Linthorst, H. J., and Bol, J. F. 1991. Differential induction of acquired resistance and PR gene expression in tobacco by virus infection, ethephon treatment, UV light and wounding. Plant Mol. Biol. 17:1117-1125.

Brooks, D. M., Bender, C. L., and Kunkel, B. N. 2005. The Pseudomonas syringae phytotoxin coronatine promotes virulence by overcoming salicylic acid-dependent defences in Arabidopsis thaliana. Mol. Plant Pathol. 6:629-639.

Brooks, D. M., Hernández-Guzman, G., Kloek, A. P., Alarcón-Chaidez, F., Sreedharan, A., Rangaswamy, V., Peñaloza-Vázquez, A., Bender, C. L., and Kunkel, B. N. 2004. Identification and characterization of a welldefined series of coronatine biosynthetic mutants of Pseudomonas syringae pathovar tomato DC3000. Mol. Plant-Microbe Interact. 17:162174

Chen, H., McCaig, B.C., Melotto, M., He, S.Y., and Howe, G.A. 2004. Regulation of plant arginase by wounding, jasmonate, and the phytotoxin coronatine. J. Biol. Chem. 279: 45998-46007.

Chini, A., Fonseca, S., Fernández, G., Adie, B., Chico, J. M., Lorenzo, O., García-Casado, G., López-Vidriero, I., Lozano, F. M., Ponce, M. R., Micol, J. L., and Solano, R. 2007. The JAZ family of repressors is the missing link in jasmonate signalling. Nature 448:666-71.

Church, G. M., and Gilbert, W. 1984. Genomic Sequencing. Proc. Natl. Acad. Sci. U.S.A. 81: 1991-1995.

Couch, R. D., O'Connor, S. E., Seidle, H. F., Walsh, C. T., and Parry, R. J. 2004. Characterization of $\mathrm{CmaA}$, an adenylation-thiolation didomain enzyme involved in the biosynthesis of coronatine. J. Bacteriol. 186:35-42.

Cuppels, D. 1986. Generation and characterization of $\operatorname{Tn} 5$ insertion mutations in Pseudomonas syringae pv. tomato. Appl. Environ. Microbiol. 51:323-327.

Delessert, C., Kazan, K., Wilson, I. W., Van Der Straeten, D., Manners, J., Dennis, E. S., and Dolferus, R. 2005. The transcription factor ATAF2 represses the expression of pathogenesis-related genes in Arabidopsis. Plant J. 43:745-757.

Devash, Y., Okon, Y., and Henis, Y. 1980. Survival of Pseudomonas tomato in soil and seeds. Phytopath Z. 99:175-185.

Elizabeth, S. V., and Bender, C. L. 2007. The phytotoxin coronatine from Pseudomonas syringae pv. tomato DC3000 functions as a virulence factor and influences defense pathways in edible Brassicas. Mol. Plant Pathol. 8:83-92.

Fan, J., Crooks, C., and Lamb, C. 2007. High-throughput quantitative luminescence assay of the growth in planta of Pseudomonas syringae chromosomally tagged with Photorhabdus luminescens luxCDABE. Plant J. 53:393-399

Gitaitis, R. D. 1990. Survey of phytopathogenic bacteria recovered from commercial tomato seed and their secondary spread within tomato transplant fields. Pages 293-298 in: Proceedings of the 7th International Conference on Plant Pathogenic Bacteria. Budapest, Hungary.

Glazebrook, J., Rogers, E. E., and Ausubel, F. M. 1997. Use of Arabidopsis for genetic dissection of plant defense responses. Annu. Rev. Genet. 31:547-569.

Gnanamanickam, S. S., Starratt, A. N., and Ward, E. W. B. 1982. Coronatine production in vitro and in vivo and its relation to symptom development in bacterial blight of soybean. Can. J. Bot. 60:645-650

Goode, M. J., and Sasser, M. 1980. Prevention-The key to controlling bacterial spot and bacterial speck of tomato. Plant Dis. 64:831-834.

Guo, Y., and Gan, S. 2006. AtNAP, a NAC family transcription factor, has an important role in leaf senescence. Plant J. 46:601-612.

Ichihara, A., Shiraishi, K., Sato, H., Sakamura, S. Nishiyama, K., Sakai, R., Furusaki, A., and Matsumoto, T. 1977. The structure of coronatine. J. Am. Chem. Soc. 99:636-637

Jensen, M. K., Rung, J. H., Gregersen, P. L., Gjetting, T., Fuglsang, A.T., Hansen, M., Joehnk, N., Lyngkjaer, M. F., and Collinge, D. B. 2007. The HvNAC6 transcription factor: A positive regulator of penetration resistance in barley and Arabidopsis. Plant Mol Biol. 65:137-150.

Kang, J.-H., Wang, L., Giri, A., and Baldwin, I. T. 2006. Silencing of threonine deaminase and JAR4 in Nicotiana attenuata impairs jasmonic acid-isoleucine-mediated defenses against Manduca sexta. Plant Cell 18:3303-3320.

Katagiri, F., Thilmony, R., and He, S. Y. 2002. The Arabidopsis thalianaPseudomonas syringae Interaction. Pages 1-35 in: The Arabidopsis Book. C. R. Somerville and E. M. Meyerowitz, eds., American Society of Plant Biologists, Rockville, MD, U.S.A.

King, E. O., Ward, N. K., and Raney, D. E. 1954. Two simple media for the demonstration of pyocyanin and fluorescein. J. Lab. Clin. Med. 44:301-307.
Krumm, T., Bandemer, K., and Boland, W. 1995. Induction of volatile biosynthesis in the lima bean (Phaseolus lunatus) by leucine and isoleucine conjugates of 1-oxo- and 1-hydroxyindan-4-carboxylic acid: Evidence for amino acid conjugates of jasmonic acid as intermediates in the octadecanoid signaling pathway. FEBS (Fed. Eur. Biochem. Soc.) Lett. 377:523-529.

Kunkel, B. N., Agnew, A., Collins, J., Cohen, J., and Chen, Z. 2004. Molecular genetic analysis of AvrRpt2 activity in promoting virulence of Pseudomonas syringae. Pages 92-102 in: Genomic and Genetic Analysis of Plant Parasitism and Defense. J. Leach, S. Tsuyumu, T. Wolpert and T. Shirashi, eds., American Phytopathological Society Press. St. Paul, MN, U.S.A.

Laurie-Berry, N., Joardar, V., Street, I. H., and Kunkel, B. N. 2006. The Arabidopsis thaliana Jasmonate Insensitive 1 gene is required for suppression of salicylic acid-dependent defenses during infection by Pseudomonas syringae. Mol. Plant-Microbe Interact. 19:789-800.

Lorenzo, O., Chico, J. M., Sanchez-Serrano, J. J., and Solano, R. 2004. JASMONATE-INSENSITIVE1 encodes a MYC transcription factor essential to discriminate between different jasmonate-regulated defense responses in Arabidopsis. Plant Cell 16:938-1950.

Lund, S. T., Stall, R. E., and Klee, H. J. 1998. Ethylene regulates the susceptible response to pathogen infection in tomato. Plant Cell 10:371382.

McCarter, S., Jones, J., Gitaitis, D., and Smitley, D. 1983. Survival of Pseudomonas syringae pv. tomato in association with tomato seed, soil, host tissue, and epiphytic weed hosts in Georgia. Phytopathology 73:1393-1398.

Melotto, M., Underwood, W., Koczan, J., Nomura, K., and He, S. Y. 2006. Plant stomata function in innate immunity against bacterial invasion. Cell 126:969-980.

Mittal, S. M., and Davis, K. R. 1995. Role of the phytotoxin coronatine in the infection of Arabidopsis thaliana by Pseudomonas syringae pv. tomato. Mol. Plant-Microbe Interact. 8:165-171.

Mysore, K. S., Crasta, O. R., Tuori, R. P., Folkerts, O., Swirsky, P. B., and Martin, G. B. 2002. Comprehensive transcript profiling of Pto- and Prfmediated host defense responses to infection by Pseudomonas syringae pv. tomato. Plant J. 32:299-315.

Nickstadt, A., Thomma, B. P. H. J., Feussner, I., Kangasjärvi, J., Zeier, J., Loeffler, C., Scheel, D., and Berger, S. 2004. The jasmonate-insensitive mutant jin1 shows increased resistance to biotrophic as well as necrotrophic pathogens. Mol. Plant Pathol. 5:425-434.

Olsen, A. N., Ernst, H. A., Leggio, L. L., and Skriver, K. 2005. NAC transcription factors: Structurally distinct, functionally diverse. Trends Plant Sci. 10:79-87.

Palmer, D. A., and Bender, C. L. 1995. Ultrastructure of tomato leaf tissue treated with the pseudomonad phytotoxin coronatine and comparison with methyl jasmonate. Mol. Plant-MicrobeInteract. 8:683-692.

Parry, R. J., Mhaskar, S. V., Lin, M.-T., Walker, A. E., and Mafoti, R. 1994. Investigations of the biosynthesis of the phytotoxin coronatine. Can. J. Chem. 72:86-99.

Peñaloza-Vázquez, A., Preston, G. M., Collmer, A., and Bender, C. L. 2000. Regulatory interactions between the Hrp type III protein secretion system and coronatine biosynthesis in Pseudomonas syringae pv. tomato DC3000. Microbiology 146:2447-2456.

Petersen, M., Brodersen, P., Naested, H., Andreasson, E., Lindhart, U., Johansen, B., Nielsen, H. B., Lacy, M., Austin, M. J., Parker, J. E., Sharma, S. B., Klessig, D. F., Martienssen, R., Mattsson, O., Jensen, A. B., and Mundy, J. 2000. Arabidopsis MAP kinase 4 negatively regulates systemic acquired resistance. Cell 103:1111-1120.

Pilowsky, M., and Zutra D. 1982. Screening wild tomatoes for resistance to bacterial speck pathogen. Plant Dis. 66:46-47.

Preston, G. M. 2000. Pseudomonas syringae pv. tomato: The right pathogen, of the right plant, at the right time. Mol. Plant Pathol. 1:263-275.

Salmeron, J. M., Barker, S. J., Carland, F. M., Mehta, A. Y., and Staskawicz, B. J. 1994. Tomato mutants altered in bacterial disease resistance provide evidence for a new locus controlling pathogen recognition. Plant Cell 6:511-520.

Thilmony, R., Underwood, W., and He, S. Y. 2006. Genome-wide transcriptional analysis of the Arabidopsis thaliana interaction with the plant pathogen Pseudomonas syringae pv. tomato DC3000 and the human pathogen Escherichia coli O157:H7. Plant J. 46:34-53.

Thimm, O., Blasing, O., Gibon, Y., Nagel, A., Meyer, S., Kruger, P., Selbig, J., Muller, L. A., Rhee, S. Y., and Stitt, M. 2004. MAPMAN: A userdriven tool to display genomics data sets onto diagrams of metabolic pathways and other biological processes. Plant J. 37:914-939.

Thines, B., Katsir, L., Melotto, M., Niu, Y., Mandaokar, A., Liu, G., Nomura, K., He, S. Y., Howe, G. A., and Browse, J. 2007. JAZ repressor proteins are targets of the $\mathrm{SCF}(\mathrm{COI} 1)$ complex during jasmonate signalling. Nature 448:661-665.

Tornero, P., and Dangl, J. L. 2001. A high-throughput method for quantify- 
ing growth of phytopathogenic bacteria in Arabidopsis thaliana. Plant $\mathbf{J}$. 28:475-481.

Uppalapati, S. R., Patricia A., Weng, H., P., Palmer, D. A., Mitchell, R. E. Jones, W., and Bender, C. L. 2005. The phytotoxin coronatine and methyl jasmonate impact multiple phytohormone pathways in tomato. Plant J. 42:201-217.

Uppalapati, S. R., Ishiga, Y., Wangdi, T., Kunkel, B. N., Anand, A., Mysore K. S., and Bender, C. L. 2007. The phytotoxin coronatine contributes to pathogen fitness and is required for suppression of salicylic acid accumulation in tomato inoculated with Pseudomonas syringae pv. tomato DC3000. Mol. Plant-Microbe Interact. 20:955-965.

Urbanczyk-Wochniak, E., Usadel, B., Thimm, O., Nunes-Nesi, A., Carrari, F., Davy, M., Blasing, O., Kowalczyk, M., Weicht, D., Polinceusz, A., Meyer, S., Stitt, M., and Fernie, A. R. 2006. Conversion of MapMan to allow the analysis of transcript data from Solanaceous species: Effects of genetic and environmental alterations in energy metabolism in the leaf. Plant Mol Biol. 60:773-992.

Usadel, B., Nagel, A., Thimm, O., Redestig, H., Blaesing, O. E, PalaciosRojas, N., Selbig, J., Hannemann, J., Piques, M. C., Steinhauser, D., Scheible, W. R., Gibon, Y., Morcuende, R., Weicht, D., Meyer, S., and Stitt, M. 2005. Extension of the visualization tool MapMan to allow statistical analysis of arrays, display of corresponding genes, and comparison with known responses. Plant Physiol. 138:1195-1204.

Vaillancourt, F. H., Yeh, E., Vosburg, D. A., O'Connor, S. E., and Walsh, C. T. 2005. Cryptic chlorination by a non-haem iron enzyme during cyclopropyl amino acid biosynthesis. Nature 436:1094-1095.

Vandesompele, J., De Preter, K., Pattyn, F., Poppe, B., Van Roy, N., De Paepe, A., and Speleman, F. 2002. Accurate normalization of real-time quantitative RT-PCR data by geometric averaging of multiple internal control genes. Genome Biol. 3:0034.1-0034.11.

Wang, K., Kang, L., Anand, A., Lazarovits, G., and Mysore, K.S. 2007. Monitoring in planta bacterial infection at both cellular and whole-plant levels using the green fluorescent protein variant GFPuv. New Phytol. $174: 212-223$

Wangdi, T. 2007. Application of a fast-forward genetic tool to identify plant genes involved in the perception of coronatine, a phytotoxin produced by Pseudomonas syringae pv. tomato DC3000. Ph.D. dissertation, Oklahoma State University, Stillwater, OK, U.S.A.

Walters, D. R. 2003. Polyamines and plant disease. Phytochemistry 64:97107.

Whalen, M. C., Innes, R. W., Bent, A. F., and Staskawicz, B. J. 1991. Identification of Pseudomonas syringae pathogens of Arabidopsis and a bacterial locus determining avirulence on both Arabidopsis and soybean. Plant Cell 3:49-59.

Zhao, Y., Thilmony, R., Bender, C. L., Schaller, A., He, S. Y., and Howe, G. A. 2003. Virulence systems of Pseudomonas syringae pv. tomato promote bacterial speck disease in tomato by targeting the jasmonate signaling pathway. Plant J.36:485-499.

\section{AUTHOR-RECOMMENDED INTERNET RESOURCES}

Bioconductor's LIMMA software: www.bioconductor.org Cornell University's Tomato expression database: ted.bti.cornell.edu

Oklahoma State University Microarry Core Facility's GenePix Autoprocessor (GPAP) software: darwin.biochem.okstate.edu/gpap3 